\title{
Morpho-physiological and Yield Responses Associated with Plant Density Variation in Soybean (Glycine max L. (Merrill))
}

\author{
Sichilima I. ${ }^{1}$, Mataa M. ${ }^{2}$, Mweetwa A.M. ${ }^{3}$ \\ ${ }^{1}$ Seed Control and Certification Institute, P.O. Box 350199, Chilanga, Zambia \\ ${ }^{2,3}$ The University of Zambia, School of Agriculture Sciences-Crop Science Department. P.O. Box 32379, Lusaka, Zambia
}

\begin{abstract}
Understanding morpho-physiological factors associated with yield decline at high density in soybean (Glycine max L.) can assist in optimizing productivity and seed quality. The objective of this study was to determine effects of different spacing on development and seed quality. The study tested the concept of yield plasticity. Five varieties that included determinate (SC Safari, Dina and Magoye) and indeterminate (Kaleya and Pan 1867) and three densities (300,000, 400,000 and 550,000 plants/ha) were used. A randomized complete block design arranged in 2 factor-factorial with variety and plant density and 4 replications was used. The experiment was done at Seed Control and Certification Institute in Chilanga, Zambia in 2015. Parameters assessed included: height, branches/plant, chlorophyll, nitrogen, $50 \%$ flowering, pod-fill time, maturity duration, biomass, seed quality, yield and yield components. Significant effects for variety were present for all parameters while plant density effects were highly significant for number of branches/plant, biomass yield, pods/plant, seeds/pod and yield. Interaction effects were observed for pods/plant and seeds/plant. Traits positively and significantly correlated to yield were height, canopy biomass yield, pods/plant and seeds/plant. Biomass, pods/plant, seeds/plant and 100 seed weight contributed significantly to total variation of grain yield. Plant height, biomass yield, number of pods/plant, number of seeds/plant and hundred seed weight were critical parameters determining yield elasticity. Kaleya, Pan 1867 and Dina appeared more tolerant of planting at high density.
\end{abstract}

Keywords - Soybean, density, yield decline, morphophysiological, determinate and indeterminate.

\section{INTRODUCTION}

Soybean (Glycine max L. Merrill) is one of the important sources of food and feed. It is one of nature's most versatile plants, and produces an abundant supply of protein and oil in both temperate and tropical environments (Harold and Fudi, 1992). In addition to being a profitable cash crop, the high protein content (about $40 \%$ ) in soybean means it could also contribute to improved nutritional status of rural households. Soybean also has agronomic benefit of rejuvenating soils by fixing atmospheric nitrogen into the soil and improving the organic matter content when plant root residues decay (Lubungu et al. 2013).

Soybeans serve a variety of functions in the global food chain, ranging from use as edible oil to a source of protein for humans to use in livestock feed. Globally, approximately 87 per cent of all soybeans are crushed into soy meal and soy oil, with the remaining 13 per cent used for direct human consumption. The products derived from the soybean crushing process, consist approximately $80 \%$ soy meal for use in animal feed; 1 and $20 \%$ vegetable oil for human consumption and as a biofuel feedstock, respectively. Soybean cultivation is concentrated within four countries-USA, Brazil, Argentina and China-accounting for almost $90 \%$ of world output while Asia (excluding China) and Africa, the two regions where most of the food insecure countries are located, together account for only $5 \%$ of production of soybean. Among countries classified as undernourished, only India and Bolivia are significant producers of soybeans (IISD, 2014).

Low yields (less than 1 ton/ha in tropical Africa) and a shortage of fertilizer constrain the ability of some countries to increase production (IITA, 2009). Soya byproducts provide low cost, high quality protein to feed rations. With a livestock sector projected to increase, soybean demand is anticipated to increase which offers significant opportunity for smallholder farmers to improve their cash base (Lubungu et al., 2013). New varieties of soybean are continuously being developed but production recommendations largely remain unchanged. It is postulated that further improvement in yield and higher resource use efficiencies (land, water and nutrients) are possible with improved agronomic/management practices (Wallace and Wallace, 1993). Accelerated population increase and emergence of 
extreme climate- situation described as perfect storm by Godfray et al. (2010) have combined to reduce access to food and other agricultural products. This situation calls for adoption of strategies such as Sustainable Intensification which seeks to increase yields on less amount of land (Robinson et al., 2010). Increasing planting densities has been used on some cereals. Plant spacing and population reduction at critical growth stages has effects on plant physiological and morphological development and grain quality. Although yield decline at high population densities is known and soybean is known to have significant plant plasticity in terms of yield, the morphological and physiological changes that underlie this decline are not clearly understood.

Therefore, the objective of this study was to determine the effects of different plant spacing on whole plant development, yield and seed quality on selected Zambian soybean varieties. Specifically the study determined:

The effect of different plant spacing on soybean whole plant development, the effect of different plant spacing on soybean yield and the plant spacing effect on post-harvest seed quality by assessing germination and vigour. It is anticipated that the findings of this study will contribute to the understanding of the effect of different plant densities on plant development and seed quality in soybean.

\section{MATERIALS AND METHODS}

2.1 Location of experimental site

The study was conducted at the Seed Control and Certification Institute situated $15^{\circ} 32.772^{\prime} \mathrm{S}$ and $28^{\circ}$ 15.796' $\mathrm{E}$ and 1,246 $\mathrm{m}$ above sea level in Chilanga district of Lusaka Province of Zambia from December
2014 to April 2015. The length of the growing period for the plants ranged from 117 to 152 days. Planting was done on the $21^{\text {st }}$ of December, 2014 and harvest was done by $22^{\text {nd }}$ April, 2015. Some intra-seasonal dry spells were experienced. The USDA Soil classification terms the soils as being Ultic Haplustalf.

\subsection{Soil Chemical Analysis}

Soil chemical analysis for the experimental site were determined as $\mathrm{pH}\left(\mathrm{CaCl}_{2}\right)$ being 6.4 which was considered slightly acid, Organic C (\%) was $0.56 \%$, considered to be low while Nitrogen content ( $\mathrm{N} \%$ ) was 0.03 and was considered to be very low. Exchangeable bases concentrations $(\mathrm{cmol} / \mathrm{kg}$ soil) were found to be Phosphorus ( $\mathrm{P}^{3-} 0.129$ considered low), Potassium $\left(\mathrm{K}^{+}\right.$ determined as 2.483 considered to be moderate) and Calcium $\left(\mathrm{Ca}^{2+}\right.$ found as 70 and considered to be high) (Bray et al, 1945).

\subsection{Plant materials used}

Five soybean genotypes were planted in the field obtained from seed companies. Selection of the genotypes was mainly based on differences in growth habits (determinant and indeterminate). Details of these varieties are presented in Table 1. Planting was done by drilling and ensuring that seeds were evenly spaced. Upon germination, stands were thinned to maintain the stated plant populations of 300,000 (D1), 400,000 (D2) and 550,000 (D3) plants $\mathrm{Ha}^{-1}$ ).

Basal dressing fertilizer was applied soon after germination at the rate of $20 \mathrm{~kg} \mathrm{~N}, 40 \mathrm{~kg} \mathrm{P}_{2} \mathrm{O}_{5}$ and $20 \mathrm{~kg}$ $\mathrm{K}_{2} \mathrm{O}$ (D Compound) per ha following the recommendations (Miti, 1995). Normal agronomical practices for growing soybean were followed.

Table.1: Soybean (Glycine max) materials used in the experimental trial

\begin{tabular}{lllll}
\hline Variety & *Growth Type & *Nodulation & Origin & Year released \\
\hline SC Safari & Determinant & Non promiscuous & SeedCo International (Z) Ltd & 2004 \\
Dina & Determinate & Non promiscuous & Maize Research Institute & 2003 \\
Magoye & Determinant & Promiscuous & Zambia Seed Company Ltd & 1981 \\
Kaleya & Indeterminate & Non & Zambia Seed Company Ltd & 1981 \\
& & promiscuous & & 2010 \\
Pan 1867 & Indeterminate & Non promiscuous & Pannar Seeds (Z) Ltd & \\
\hline
\end{tabular}

Source: SCCI 2013 Variety Register

\subsection{Data collection}

Data was collected on morphological and physiological traits as well as on yield and yield components. Data on vegetative and reproductive parameters was collected during the different development phases of the crop.

2.4.1 Plant height 
Plant height was measured with use of a ruler at R6-R7 growth stage. This is because at this point the plant had attained its full height and root growth had ceased. Delaying to collect plant height data could lead to obtaining inaccurate results because at this point lodging and leaf fall associated with senescence would have set in (Casteel, 2011; Mc Williams, 1999).

\subsubsection{Number of branches}

The number of branches was measured by counting five plants at random and averaging the result at between R5 and R7 stage. The number of branches has a bearing on final yield obtained as pods tend to be borne on the branches. Many researchers have a positive correlation between the number of branches, pods and yield.

\subsubsection{Chlorophyll content}

Chlorophyll content (between V4 and V6) was obtained by use of Chlorophyll meter (Konica Minolta Spad 502Plus). SPAD chlorophyll meter reading (SCMR) is a quick, non- destructive measurement of the chlorophyll content of plant leaves (Moe, 2012).

\subsubsection{N-Content}

Nitrogen content assessment was done at the R3 growth stage when nitrogen fixation and nodulation are expected to be occurring. Leaves were sampled, dried at $65^{\circ} \mathrm{C}$ in an open air circulating oven and crushed (Peoples et al, 1989; UNZA, 2014) before laboratory analysis for Nitrogen content using the Kjeldahl method.

2.4.5 Biomass weight at R3 and at harvest (Canopy biomass)

Biomass was determined by sampling 5 plants per replication at the $\mathrm{R} 3$ growth stage and drying them at 65 ${ }^{0} \mathrm{C}$ for 48 hours (Peoples et al, 1989) before weighing them. This was done to compare the weights of the three population densities. The biomass weight at harvest was obtained by sampling five plants at harvest time (R8) per replication and weighing them. At this stage, most roots had senesced and could not be harvested as part of total biomass so the canopy biomass instead was what was determined. The biomass weight was expressed as $\mathrm{kg} / \mathrm{m}^{2}$. 2.4.6 Yield and 100 seed weight

Yield was calculated as a function of base population, pod number, seeds per pod and seed weight (Casteel, 2011) at the harvestable moisture content of $15 \%$. Seed weights were obtained by counting 100 seeds in three replicates, weighing them and obtaining an average to come up with an accurate 100 seed weight.

\subsubsection{Days to $50 \%$ flowering}

The days to $50 \%$ flowering occurs at the time a plant begins its reproductive growth phase. At this stage, about $50 \%$ of flowers are fully open (UPOV, 1998). The number of days were calculated from the time of plant emergence to when the plants reach $50 \%$ flowering and data was collected at the R1-R2 growth stage.
2.4.8 Days to pod filling

The total number of days from emergence to this stage was calculated as the days to pod filling. Maturity of genotypes differed on time taken to fill the pods. Full seed occurs at R6 growth stage and this stage is also known as the "green bean stage" (Mc Williams et al. 1999).

2.4.9 Days to maturity

The number of days was calculated from emergence to R8. This was the plant's whole growth period and determined varietal maturity differences and effects of plant density.

2.4.10 Number of seeds per plant and number of pods per plant

The number of seeds per plant was calculated by multiplying averages of locules per pod and pods per plant. Like the number of pods per plant, the number of seeds per plant contributes to the determination of the final yield (Casteel, 2011). The number of pods per plant was determined by counting pods of five sampled plants and finding the mean number of pods per plant. This was done at the R7-R8 growth stage when all the pods had fully formed and matured. The number of pods per plant is a significant factor in determining the plant yield (Casteel, 2011).

\subsubsection{Field design}

The field trial was laid out as a randomized complete block design arranged in 2 factor- factorial with variety and plant density and 4 replications used (Gomez and Gomez, 1984). The genotypes Kaleya, Magoye, Pan 1869, Sc Safari and Dina were the varieties assigned. The three plant population densities used were 300,000 plants/ha (D1), 400,000 plants/ha (D2) and 550,000 plants/ha (D3). The 400,000 plants/ha is the recommended plant population in Zambia (Miti, 1995).

2.4.12 Data analysis

Data was analyzed using the statistical package GenStat Version 12. Means were subjected to analysis of variance (ANOVA) where significant treatment effects were detected, mean separation was done using the least significant difference (LSD) and Bonferroni test for multiple comparisons. Relationships between selected parameters were determined using the Pearson's simple correlation test.

\section{RESULTS}

Results in Table 2 show that there were significant differences in treatment responses among the five varieties. The Population density used was significant for the parameters measured for yield $(\mathrm{P}=0.02)$, number of seeds per pod $(\mathrm{P}=0.005)$, pods per plant $(\mathrm{P}=0.004)$, biomass weight at $\mathrm{R} 3$ growth stage $(\mathrm{P}<0.001)$, biomass weight at harvest $(\mathrm{P}<0.001)$ and number of branches per 
plant $(\mathrm{P}<0.001)$. Significant interaction between genotype

number of pods per plant were observed.

and population density for number of seeds per pod and

Table.2: Summary of ANOVA of treatment effects on 5 genotypes of soybeans (Glycine max) subjected to three levels of plant

\begin{tabular}{|c|c|c|c|c|c|c|c|c|c|c|c|c|c|c|c|c|c|}
\hline & & & & & & & & & & & & & & & & & \\
\hline $\begin{array}{l}\text { Source of } \\
\text { variation }\end{array}$ & $\begin{array}{l}\text { D. } \\
\text { F. }\end{array}$ & PH & NB & $\begin{array}{l}\text { Ch } \\
\text { l } \\
\text { T1 }\end{array}$ & $\begin{array}{l}\text { Ch } \\
\text { l } \\
\text { T2 }\end{array}$ & $\mathrm{NC}$ & $\begin{array}{l}50 \\
\% \\
\text { DF }\end{array}$ & $\begin{array}{l}\text { DP } \\
\text { F }\end{array}$ & $\begin{array}{l}\text { DF } \\
\text { M }\end{array}$ & $\begin{array}{l}\text { B } \\
\text { M }_{1}\end{array}$ & $\begin{array}{l}\text { B } \\
\mathbf{M}_{2}\end{array}$ & $\begin{array}{l}\text { NP } \\
\text { D }\end{array}$ & $\begin{array}{l}\text { NS } \\
\text { D }\end{array}$ & $\begin{array}{l}\mathbf{S} \\
\mathbf{W}\end{array}$ & Yd & G & SV \\
\hline $\begin{array}{l}\text { Rep stratum } \\
\text { Rep.*Units* } \\
\text { stratum }\end{array}$ & 3 & $\mathrm{~ns}$ & ns & $\mathrm{ns}$ & $\mathrm{ns}$ & ns & $\mathrm{ns}$ & $\mathrm{ns}$ & ns & ns & $\mathrm{ns}$ & $\mathrm{ns}$ & $\mathrm{ns}$ & $\mathrm{ns}$ & $\mathrm{ns}$ & ns & $\mathrm{ns}$ \\
\hline Variety & 4 & $* *$ & $* *$ & ** & $* *$ & * & * & $* *$ & $* *$ & $* *$ & $*$ & $* *$ & $* *$ & $* *$ & $* *$ & ** & $* *$ \\
\hline $\begin{array}{l}\text { Density } \\
\text { Density x }\end{array}$ & 2 & ns & ** & ns & $\mathrm{ns}$ & $\mathrm{ns}$ & ns & $\mathrm{ns}$ & ns & $* *$ & $* *$ & ** & $* *$ & $\mathrm{~ns}$ & $*$ & ns & $\mathrm{ns}$ \\
\hline $\begin{array}{l}\text { Variety } \\
\text { Residual }\end{array}$ & $\begin{array}{r}8 \\
42\end{array}$ & ns & ns & ns & ns & ns & ns & ns & ns & ns & ns & $*$ & $*$ & ns & ns & ns & $\mathrm{ns}$ \\
\hline Total & 59 & & & & & & & & & & & & & & & & \\
\hline CV \% & & 4.4 & 4.3 & 2.8 & 2.4 & $\begin{array}{r}17 . \\
2\end{array}$ & 0.1 & 0.1 & 6.7 & 8.8 & 8.5 & $\begin{array}{r}11 . \\
2\end{array}$ & $\begin{array}{r}11 . \\
3\end{array}$ & 3.0 & $\begin{array}{r}13 . \\
7\end{array}$ & 3.6 & 3.5 \\
\hline
\end{tabular}

Level of significance: $n s \quad$ : non- significant, * : significant at $\mathrm{P}=0.05, * *$ : significant at $\mathrm{P} \leq 0.001$.

3.1 Effect of genotype and plant population density for the morpho-physiological traits

Results in Table 3 for number of branches indicated that the effect of variety $(\mathrm{p}<0.001)$ and of density $(\mathrm{p}<0.001)$ was highly significant but the effect of the interaction was not. The highest number of branches were recorded from genotype Kaleya ( 5 branches/plant) followed by Pan 1867 (4 branches/plant) while the least number of branches per plant were recorded from Dina (3 branches/plant). A trend showed reduced numbers of branches per plant as plant density was increased from D1 (4.3 branches) to D2 (4.1 branches) and to D3 (3.2 branches).

The results show that the main effect of variety on biomass yield at both R3 $(\mathrm{p}<0.001)$ and at R8 $(\mathrm{p}<0.018)$ growth stages was significant as was the main effect of density (Table 3) while the interaction of the two factors was non-significant. The variety Dina had the highest biomass $\left(23.95 \mathrm{~kg} / \mathrm{m}^{2}\right)$ at R3 growth stage followed by Magoye $\left(18.67 \mathrm{~kg} / \mathrm{m}^{2}\right)$ while SC Safari $\left(7.23 \mathrm{~kg} / \mathrm{m}^{2}\right)$ had the least biomass. The effect of plant density for biomass yield at both R3 and R8 growth stages was significant; $(\mathrm{p}<0.001)$ and $(\mathrm{p}<0.001)$, respectively.

At R8 growth stage biomass yield for variety Kaleya $\left(23.96 \mathrm{~kg} / \mathrm{m}^{2}\right)$ and Magoye $\left(23.11 \mathrm{~kg} / \mathrm{m}^{2}\right)$ were nonsignificantly different but the two varieties were significantly different from the other three varieties (Table 3). Variety SC Safari $\left(16.25 \mathrm{~kg} / \mathrm{m}^{2}\right)$, Dina (18.46 $\left.\mathrm{kg} / \mathrm{m}^{2}\right)$, and Pan $1867\left(17.42 \mathrm{~kg} / \mathrm{m}^{2}\right)$ did not show significant differences from each other. The results show a strong positive increasing trend in the amount of biomass with the rise in population density from D1 $\left(10.67 \mathrm{~kg} / \mathrm{m}^{2}\right)$ to D3 $\left(20.24 \mathrm{~kg} / \mathrm{m}^{2}\right)$ at R3 growth stage and D1 $\left(10.40 \mathrm{~kg} / \mathrm{m}^{2}\right)$ to D3 $\left(30.88 \mathrm{~kg} / \mathrm{m}^{2}\right)$ with regression constants of $\left(\mathrm{R}^{2}=0.975\right.$ at $\mathrm{R} 3$ and $\mathrm{R}^{2}=0.982$ at $\left.\mathrm{R} 8\right)$, respectively.

Significant differences $(\mathrm{p}<0.001)$ were obtained in the means for the number of pods per plant (Table 4) between genotypes Magoye (41 pods/plant) and Kaleya (31 pods/plant) and the rest of the genotypes. However, there was non-significant difference among genotypes Sc Safari (19 pods/plant), Dina (23 pods/plant) and Pan 1867 (18 pods/plant) following an LSD of 5.3. The highest number of pods per plant were obtained by genotype Magoye followed by Kaleya with the least being Pan 1867 (41 pods/plant, 31 pods/plant, 18 pods/plant) respectively. The density effects $(\mathrm{p}=0.004)$ were observed with $\mathrm{D} 1$ (29.60 pods/plant) having most than D2 (26.94 pods/plant) and D3 (22.32 pods/plant) as shown in Table 4. Interaction effects $(p=0.032)$ between variety and density were also observed Fig. 1.

Results for number of seeds per plant for variety and density are presented in Table 4 and they show that significant differences $(p<0.001)$ were obtained in the means for the number of seeds per plant for the varieties Dina (51 seeds/plant), Magoye (90 seeds/plant) and Kaleya (67 seeds/plant). However, non-significant differences were observed between Sc Safari (37 seeds/plant) and Pan 1867 (32 seeds/plant). The effect of density was also significant $(\mathrm{p}=0.005)$ with $\mathrm{D} 1, \mathrm{D} 2$ and D3 having (63.2, 56.6 and 46.5 seeds/plant), respectively. 
This result showed a reduced trend in the number of seeds/plant as density was increased. Significant differences were also observed for the variety and density effects as presented in Fig. 2.

The results obtained for yield are presented in Table 4 and indicate that the main effect of variety was significant $(p<0.001)$, as was the main effect of plant density $(p=0.018)$ but the interaction of these two factors was non-significant. The highest yield was obtained by variety Magoye (3.64 ton/ha) followed by Kaleya (3.08 ton/ha) and the least was SC Safari in D1 (1.99 ton/ha). For the density, the highest yield was obtained in D3 (3.19 ton/ha), followed by D2 (2.81 ton/ha) with the least density being D1 (2.29 ton/ha), respectively. Significant differences were observed between D1 and D3 but there was no significant difference between D1 and D2 and between D2 and D3. 
Table.3: Main effects of variety and plant density on the number of branches per plant and biomass yield of soybean (Glycine

\begin{tabular}{|c|c|c|c|}
\hline \multicolumn{4}{|c|}{$\max )$} \\
\hline Treatment & $\begin{array}{l}\text { Number of branches per } \\
\text { plant }\end{array}$ & Biomass at R3 & Biomass at harvest \\
\hline \multicolumn{4}{|l|}{ Variety } \\
\hline Sc Safari & $3.8 \mathrm{~b}$ & $7.23 \mathrm{a}$ & $16.25 \mathrm{a}$ \\
\hline Dina & $2.983 \mathrm{a}$ & $23.95 \mathrm{c}$ & $18.46 \mathrm{ab}$ \\
\hline Magoye & $3.367 \mathrm{ab}$ & $18.67 \mathrm{bc}$ & $23.11 \mathrm{bc}$ \\
\hline Kaleya & $5.35 \mathrm{c}$ & $14.21 \mathrm{ab}$ & $23.96 \mathrm{c}$ \\
\hline Pan 1867 & $4.067 \mathrm{~b}$ & $10.98 \mathrm{ab}$ & $17.42 \mathrm{a}$ \\
\hline \multicolumn{4}{|l|}{ Density } \\
\hline D1 & $4.3 \mathrm{~b}$ & $10.67 \mathrm{a}$ & $10.4 \mathrm{a}$ \\
\hline D2 & $4.18 \mathrm{~b}$ & $14.12 \mathrm{a}$ & $18.24 \mathrm{~b}$ \\
\hline D3 & $3.26 \mathrm{a}$ & $20.24 b$ & $30.88 \mathrm{c}$ \\
\hline Factor Effects & P-values & & \\
\hline Variety & $<0.001$ & $<0.001$ & 0.018 \\
\hline Density & $<0.001$ & $<0.001$ & $<0.001$ \\
\hline Variety $*$ Density & 0.218 & 0.833 & 0.466 \\
\hline
\end{tabular}

Table.4: Main effects of varieties and plant density on number of pods and seeds per plant and yield of soybean (Glycine

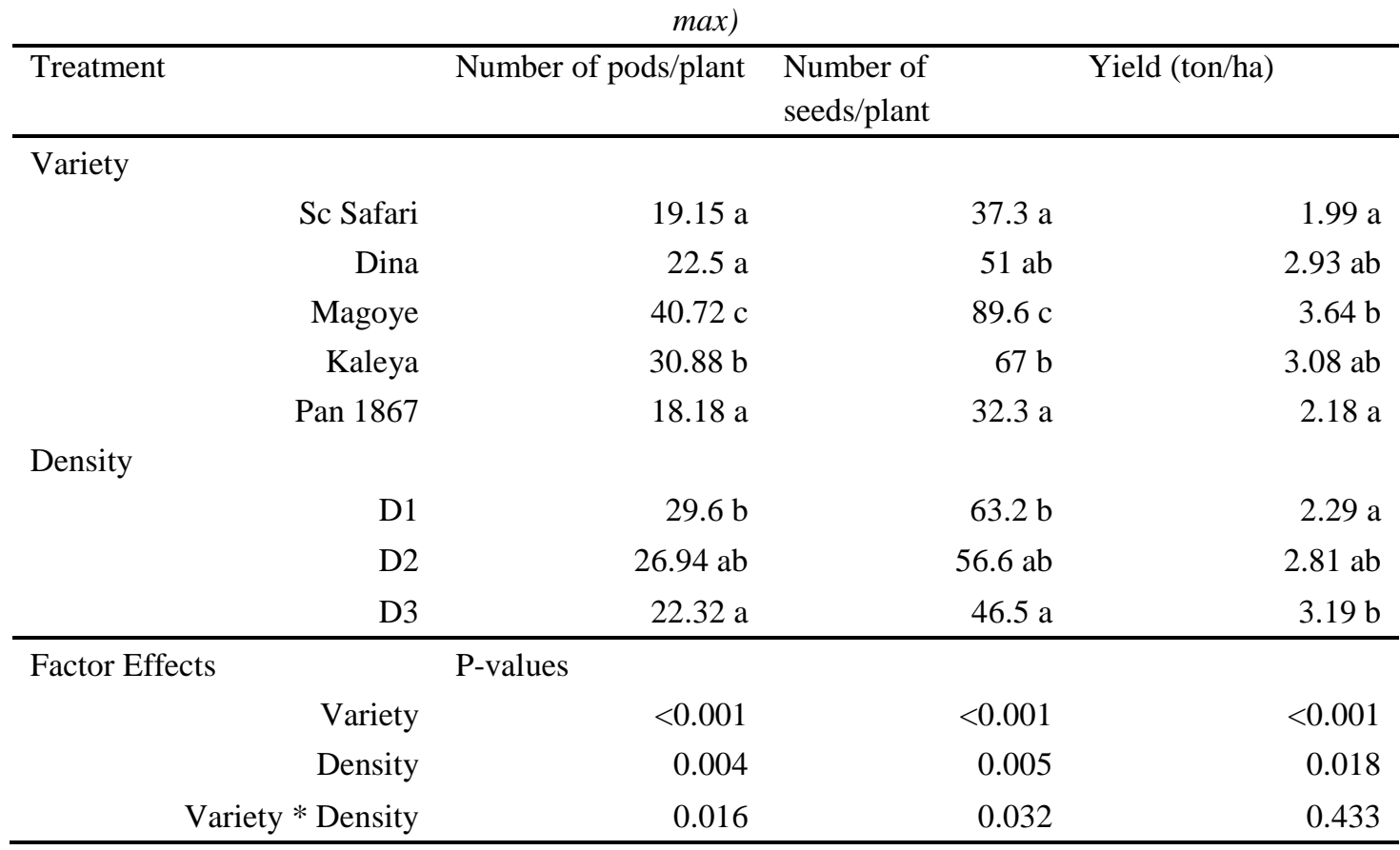




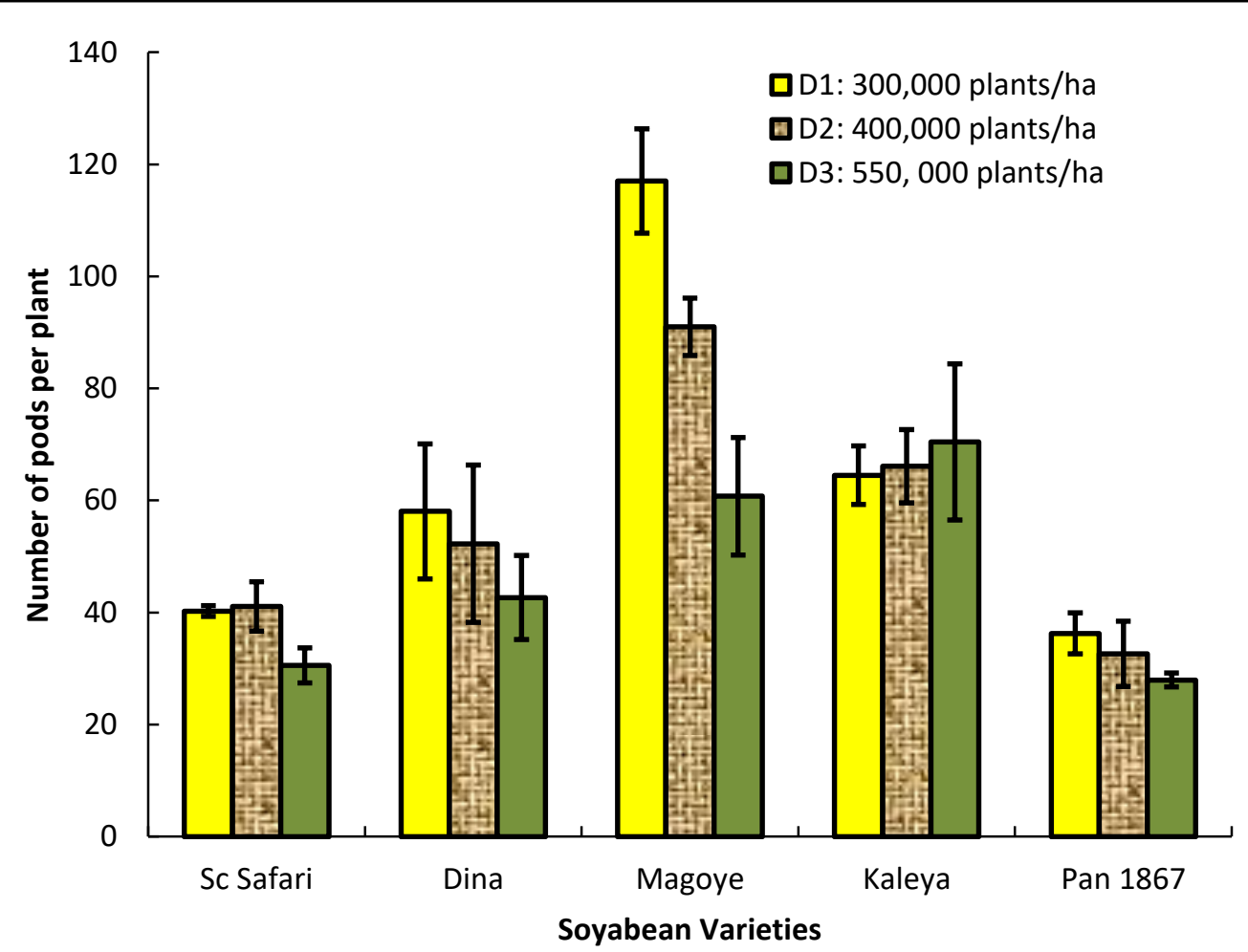

Fig.1: Interaction effect of soybean (Glycine max) variety and population density on number of pods per plant. Bars indicate standard errors of means.

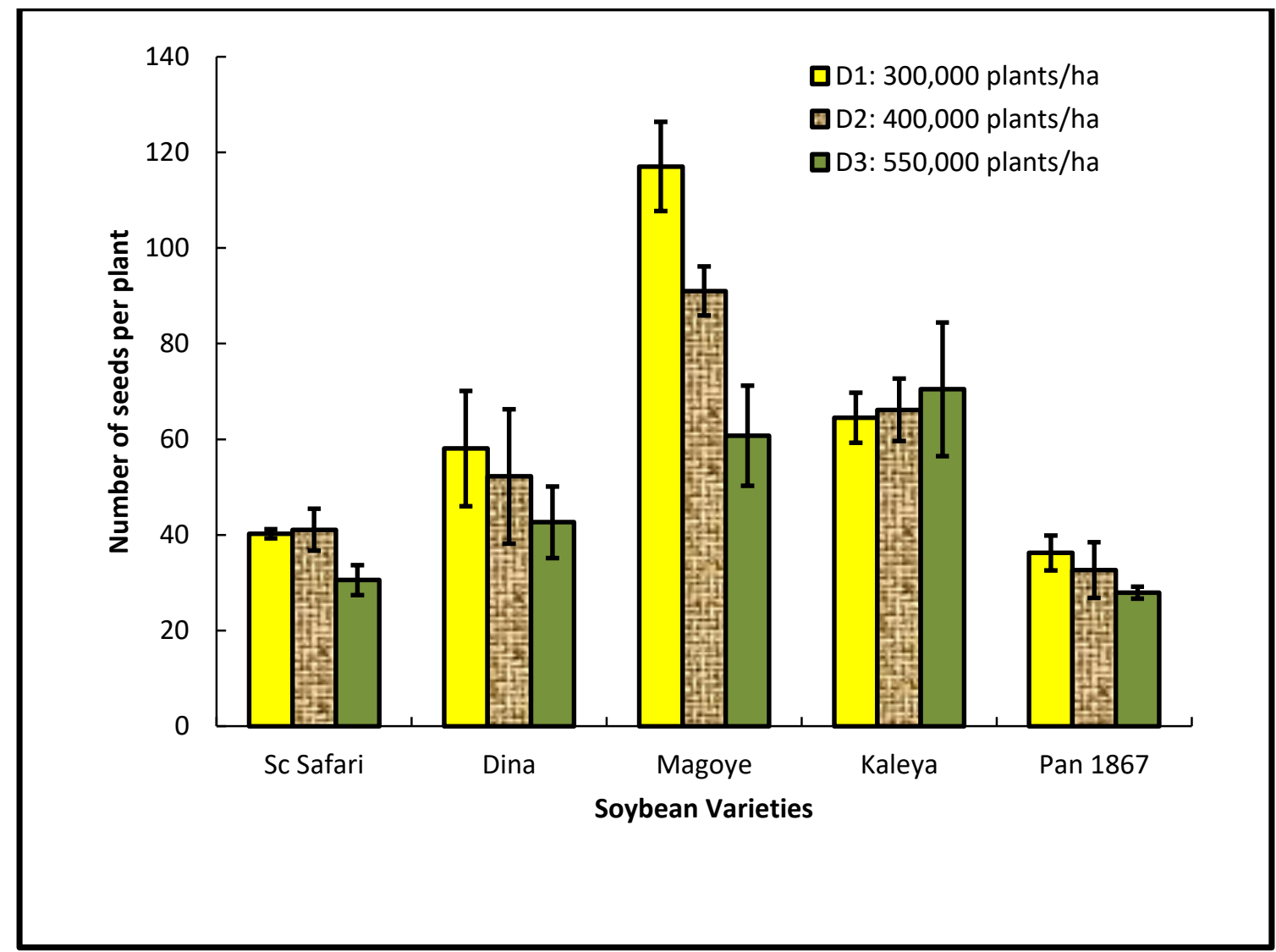

Fig.2: Interaction effect of soybean (Glycine max) variety and population density on number of seeds per plant. Bars indicate standard errors of means. 
3.2 Relationship among morpho-physiological traits, grain yield and yield components of five soyabean (Glycine max) genotypes

The strength of association for traits measured with yield as well as the inter component correlation amongst the components are here presented (Table 5). The results showed that plant height $\left(\mathrm{r}=0.58^{*}\right)$, number of pods per plant $\left(\mathrm{r}=0.70^{*}\right)$, number of seeds per plant $\left(\mathrm{r}=0.73^{*}\right)$ and biomass weight at harvest $(\mathrm{r}=0.60 *)$, were positively and significantly correlated respectively while other traits showed little positive and negative correlation.

The results recorded in Table 5 also show a strong positive and significant inter component correlation between components. Strong positive correlations were observed between plant height and $50 \%$ days to flowering $\left(\mathrm{r}=0.79^{*}\right)$, plant height and days to pod filling $(\mathrm{r}=0.74 *)$, number of pods and number of seeds $\left(\mathrm{r}=0.98^{*}\right)$, number of pods and days to maturity $\left(\mathrm{r}=0.54^{*}\right)$, number of seeds and plant height $(\mathrm{r}=0.59 *)$. A strong negative correlation was observed between hundred seed weight and $50 \%$ days to flower $(\mathrm{r}=-0.54 *)$, hundred seed weight and number of pods per plant $\left(\mathrm{r}=-0.51^{*}\right)$ and hundred seed weight and number of seeds per plant $(\mathrm{r}=$ $0.55 *)$. Other correlations not reported were either weak positive or weak negative hence not well correlated.

3.3 Stepwise multiple regression

The seed yield was used as the dependent variable while the morpho- physiological traits were used as independent variables (Table 6). Significant and small contribution to total variations was observed among the independent variables in the study. Biomass yield at harvest (R8) had a significant influence on grain yield having the highest Wald statistic of $99.99 \%$. Other variables; plant height, number of pods per plant, number of seeds per plant and hundred seed weight showed significant contributions to total variation with an average $\mathrm{R}^{2}$ of $85.3 \%$. Further additions of other variables to the model did not show significant differences, thus not included in the model. The prediction model for yield was generated as in: (1).

(1) $\mathrm{Yd}=-1.934+0.006191 \mathrm{BM}_{2}+0.1205 \mathrm{SW}+$ 0.054 NSD - 0.0478 NPD + 0.00279 PH

Table.5: Results of correlation between yield and each pair of variables for soybean (Glycine max)

\begin{tabular}{|c|c|c|c|c|c|c|c|c|c|c|c|c|c|c|}
\hline $\begin{array}{l}100 \mathrm{~S} \\
\mathrm{~W}\end{array}$ & & & & & & & & & & & & & & \\
\hline $\begin{array}{r}50 \% \\
\text { DF }\end{array}$ & $0.538^{*}$ & - & & & & & & & & & & & & \\
\hline $\mathrm{BM}_{1}$ & -0.130 & $0.562^{*}$ & - & & & & & & & & & & & \\
\hline $\mathrm{NC}$ & -0.166 & -0.120 & 0.304 & - & & & & & & & & & & \\
\hline NB & -0.077 & -0.349 & -0.413 & 0.326 & - & & & & & & & & & \\
\hline $\mathrm{BM}_{2}$ & -0.107 & 0.134 & 0.424 & -0.086 & -0.156 & - & & & & & & & & \\
\hline $\begin{array}{r}\text { Chl } \\
\text { T1 }\end{array}$ & 0.380 & $\begin{array}{r}-0.518 \\
*\end{array}$ & -0.356 & 0.042 & 0.145 & -0.213 & - & & & & & & & \\
\hline $\begin{array}{r}\text { Chl } \\
\text { T2 }\end{array}$ & 0.301 & -0.433 & -0.081 & -0.092 & 0.094 & -0.101 & $\begin{array}{c}0.587 \\
*\end{array}$ & & & & & & & \\
\hline $\begin{array}{l}\mathrm{DF} \\
\mathrm{M}\end{array}$ & -0.257 & 0.452 & 0.106 & 0.067 & -0.081 & -0.076 & 0.385 & 0.417 & - & & & & & \\
\hline DPF & -0.205 & $0.885^{*}$ & $0.632^{*}$ & -0.239 & -0.313 & 0.089 & 0.409 & 0.333 & 0.365 & - & & & & \\
\hline NSD & $\begin{array}{r}-0.550 \\
*\end{array}$ & $0.523^{*}$ & 0.095 & 0.175 & 0.279 & 0.109 & 0.401 & 0.379 & 0.490 & 0.335 & - & & & \\
\hline NPD & ${ }^{-}$ & 0.438 & 0.033 & 0.204 & 0.316 & 0.092 & $\begin{array}{r}- \\
0.401\end{array}$ & $\begin{array}{r}- \\
0.384\end{array}$ & $\begin{array}{l}0.538 \\
*\end{array}$ & 0.247 & $\begin{array}{r}0.97 \\
9^{*}\end{array}$ & - & & \\
\hline $\mathrm{PH}$ & 0.358 & $0.792^{*}$ & $0.609^{*}$ & -0.055 & -0.265 & 0.280 & 0.336 & 0.180 & 0.327 & $0.738^{*}$ & $\begin{array}{r}0.59 \\
1^{*}\end{array}$ & $\begin{array}{r}0.52 \\
9^{*}\end{array}$ & - & \\
\hline Yd & $\begin{array}{r}- \\
0.249\end{array}$ & 0.415 & 0.330 & 0.053 & 0.065 & $0.598^{*}$ & $\begin{array}{r}- \\
0.276\end{array}$ & $\begin{array}{r}- \\
0.242\end{array}$ & 0.271 & 0.336 & $\begin{array}{l}0.73 \\
3^{*}\end{array}$ & $\begin{array}{r}0.69 \\
7^{*}\end{array}$ & $\begin{array}{r}0.58 \\
4^{*}\end{array}$ & - \\
\hline & $\begin{array}{r}100 \mathrm{~S} \\
\mathrm{~W}\end{array}$ & $\begin{array}{r}50 \% \mathrm{D} \\
\mathrm{F}\end{array}$ & $\mathrm{BM}_{1}$ & $\mathrm{NC}$ & NB & $\mathrm{BM}_{2}$ & $\begin{array}{r}\text { Chl } \\
\text { T1 }\end{array}$ & $\begin{array}{r}\text { Chl } \\
\text { T2 }\end{array}$ & DFM & DPF & $\begin{array}{r}\mathrm{NS} \\
\mathrm{D}\end{array}$ & $\begin{array}{r}\text { NP } \\
\text { D }\end{array}$ & $\mathrm{PH}$ & $\begin{array}{l}\mathrm{Y} \\
\mathrm{d}\end{array}$ \\
\hline
\end{tabular}

* Correlation is significant at $\mathrm{P} \leq 0.05$. 
Table.6: Multiple regression of yield on morphological and physiological traits in soybeans (Glycine max) subjected to varying population densities

\begin{tabular}{ll}
\hline Response variate: & Yd \\
Fitted terms: & Constant, $100 \mathrm{SW}, \mathrm{BM}_{2}, \mathrm{NSD}, \mathrm{NPD}, \mathrm{PH}$
\end{tabular}

\begin{tabular}{llllll}
\hline \multicolumn{2}{l}{ Summary of analysis } & & & & \\
Source & d.f. & s.s. & m.s. & v.r. & F pr. \\
Regression & 5 & 70.66 & 14.1311 & 69.6 & $<.001$ \\
Residual & 54 & 10.96 & 0.203 & & \\
Total & 59 & 81.62 & 1.3834 & &
\end{tabular}

Estimates of parameters

\begin{tabular}{lrrrrr} 
Parameter & estimate & s.e. & $\mathrm{t}(54)$ & $\mathrm{t}$ pr. & \\
Constant & -1.934 & 0.526 & -3.68 & $<.001$ & Wald statistic \\
$\mathrm{BM}_{2}$ & 0.006191 & 0.000619 & 10 & $<.001$ & 99.99 \\
$100 \mathrm{SW}$ & 0.1205 & 0.0264 & 4.57 & $<.001$ & 20.85 \\
$\mathrm{NSD}$ & 0.054 & 0.012 & 4.48 & $<.001$ & 20.07 \\
$\mathrm{NPD}$ & -0.0478 & 0.0266 & -1.8 & 0.078 & 3.22 \\
PH & 0.00279 & 0.00513 & 0.54 & 0.588 & 0.3 \\
\hline
\end{tabular}

Percentage variance accounted for 85.3

Standard error of observations is estimated to be 0.451 .

$\underline{\text { Key: }}$

Yd: Yield

100 SW: 100 seed weight

$\mathrm{BM}_{2}$ : Biomass weight at harvest

NSD: Number of Seeds per pod

NPD: Number of Pods per plant

PH: Plant height

\section{DISCUSSION}

The present study focused on determining the effect of different plant spacing on whole plant development, yield and seed quality on selected Zambian soybean varieties and in particular, plant spacing on soybean whole plant development performance as well as seed quality parameters with particular reference to germination and vigour. The effects of density stress, like all other stresses depend on the plant development stage, the stress applied, the degree and the duration of the stress. In this study, plants were subjected to three levels of population density during the whole growth duration which resulted into a wide variation in the responses of the five genotypes to morpho-physiological traits, grain yield and yield components. A marked genotypic variability in traits measured was observed among the different genotypes. Varying plant density showed some impact on important morpho-physiological traits and grain yield and yield components in all the genotypes tested.

Differences among the genotypes as well as the plant density used in this study were significant for the number of branches. Non-significant interactions were observed. The number of branches per plant was significantly influenced by the plant density in this study. There was marked reduction in number of branches as the plant density was raised from D1 to D3. These findings are supported by several researchers who found similar results. Mehmet (2008), Bullock et al. (1998) and Ball et al. (2000) all report finding the number of branches to significantly vary among plant densities. Ayub (2011) found out that increasing the seed rates decreased the number of branches. The reason for having less number of branches at higher seed rates may be due to more competition among plants for light, space and nutrients at higher seed rates. These results are supported by the findings of Biswas et al. (1997) who observed inverse relationship between seed rate and number of branches per plant. Shamsi and Kobraee (2011) noted that the effect of cultivar on number of branches per plant was significant. In the study carried out by Çalifikan et al. (2007), branch number per plant significantly varied among the row widths which led to the conclusion that 
significant variation resulted from density differences among row widths. Plants grown in low plant density conditions received higher solar radiation compared to denser populations, which caused a greater portion of vegetative dry matter to be allocated into the branches. Therefore, plants in wider rows were capable of partitioning more resources to increase branch number in response to plant density. Consequently, the ability of soybean to branch was greater in wide rows.

Significant differences among the varieties were observed for the biomass weight at both R3 and at harvest (R8). Subjecting the genotypes to the different plant densities also had a significant effect on biomass. As the population density was lowered from the optimal (D2 to D1), biomass weight reduced, while increasing population density from optimal to higher density (D2 to D3) resulted in increased biomass weight with all varieties showing marked increment ranging from $54 \%$ to $101 \%$, with Kaleya having the highest biomass rate increment. The results are in conformity with research conducted by Squire (1990), who states that the rate at which a stand produces dry matter and the amount produced by the time it is harvested; both depend on many environmental and physiological factors. The main factors, other than solar radiation, that cause differences among the (C4 and $\mathrm{C} 3$ ) plants are plant population density, the composition of the stand and temperature. All these affect the three main attributes of a stand in different ways; these attributes being the leaf area, its conversion ratio for solar radiation and duration. The population density has a moderate effect on the conversion of intercepted radiation to dry matter, but its influence on production is mainly through leaf area index. Production therefore increases as population rises, and effectively reaches a plateau when further increase in population results in only slightly more intercepted radiation. Ayub et al. (2011) and AmissahArthur et al. (1999) found that dry matter was significantly increased with increase in seeding rates. This increase can be attributed to more plant population at given seed rates. It is also true then than biomass of an individual plant tends to reduce in higher population stands, a fact observed in this study. Sekimura et al. (2000), states that plants exhibit great morphological plasticity in their response to the environment such as the number of neighbouring plants (i.e. population density). Plant height, for instance, increases relative to [individual plant] biomass, stem diameter and leaf area as population density increases (Sekimura et al. 2000).

Significant differences among the five varieties for number of seeds per plant and pods per plant were observed. Also, the number of seeds per plant and pods per plant were significantly influenced by the three population densities in this study. The reduction in plant population from normal plant density to lower plant density (D2 to D1) resulted in the increase in the number of seeds per plant and pod number per plant while the increase from normal density (D2 to D3) resulted in lowered number of pods and seeds per plant. Similar results were obtained by Çalifikan et al. (2007), Shamsi and Kobraee (2011) and Bing et al. (2010) who reported that grain yield and number of pods per plant were declined with increasing density while Shamsi and Kobraee (2011) recorded more number of pods per plant at lower density. According to Mc Williams et al. (1999), temperature or moisture stress at (R3) can affect yield through total pod number, bean number per pod or seed size. Partial compensation with only temporary stress can occur in soybeans, but as the plant matures from R1 to R5.5 this ability to compensate will decrease. Very favourable conditions will result in greater pod number per plant at this time.

The high mean yields exhibited by genotype Magoye for all the environments could be attributed to its high number of pods per plant and number of seeds per plant which remained consistently high compared to the other genotypes across the three environments. The low yield exhibited by genotypes Sc Safari and Pan 1867 could be attributed to their shorter stature, shorter growing period and having lower number of pods and seeds per plant. The findings in this study are in agreement with Ball et al. (2000), Mehmet (2008) and Shamsi and Kobraee (2011) who all report that increasing the population reduces yield per plant but increases yield per unit area. The decreased yield per plant is more than offset by population, resulting in yield per square meter increasing to an asymptote as population increases. Variety Kaleya was the most plastic in terms of yield at $46.80 \%$ followed by Pan 1867 at $17.67 \%$ and Dina at $13.51 \%$. Despite Magoye having the highest yield overall, it did not respond plastically as density was raised from D2 to D3, Sc Safari also showed reduced yields as density was raised from D2 to D3 preferring to yield better in the optimal environment. Martin (1998) reports that large plants tend to bear a large number of seeds. Thus, seed yield potential per plant is closely related to the day length requirement of the variety and to the season of planting. It can therefore be said that the higher average yields obtained from Magoye, Kaleya and Dina could be attributed partly to their higher biomass yields. The duration of the plant growth also had an effect on the yields obtained. The average days to maturity for the genotypes (Sc Safari 120; Dina 152; Magoye165; Kaleya132; Pan 1867 117days), could explain the reason for the genotypes Magoye, Kaleya and Dina yielding more than the rest. The aspect of days to maturity is closely related to days to seed filling. Egli (1998) reports that longer seed filling periods are 
frequently associated with higher yields in many crops due to longer seed filling duration, (SFD) and resulting in a higher harvest index (HI), unless there is a proportionate increase in vegetative matter (VM).

There were significant differences among the genotypes for post-harvest seed germination as well as vigour. However, non-significant differences were observed for the plant density for the two parameters despite results showing slight reduction in germination and vigour with increase in plant density. Similar results were found in an experiment conducted by Shena et al. (2011) where increasing plant population resulted in reduced vigour, but, the differences were not significant at any densities. These results differ from those found by Castillo (1992), where in his experiment with garden peas (Pisum sativum L.), seeds from a population of 200 plants $\mathrm{m}^{-2}$ and $10 \mathrm{~cm}$ row width harvested at $15 \%$ seed moisture content had lower vigour than less dense plantings, a fact attributed to high temperature and relative humidity within the crop canopy.

The strength of association for traits measured with yield as well as the inter component correlation amongst the components showed that plant height $\left(\mathrm{r}=0.584^{*}\right)$, number of pods per plant $\left(\mathrm{r}=0.697^{*}\right)$, number of seed per plant $\left(\mathrm{r}=0.733^{*}\right)$ and biomass yield at harvest $(\mathrm{r}=$ $0.598 *$ ), were positively and significantly correlated. To assess the cause and effect of yield in regression analysis, yield was used as the dependent variable while the morpho- physiological traits were used as independent variables. Significant and small contribution to total variations was observed among the independent variables in the study. Biomass yield at harvest had a significant influence on yield having the highest Wald statistic of $99.99 \%$. Other variables; plant height, number of pod per plant, number of seeds per plant and hundred seed weight showed significant contributions to total variation. Therefore biomass yield had the most influence on the observed yield as reported by Duncan (1986).

\section{CONCLUSION}

Use of different soybean varieties showed significant differences in all parameters studied. Varying plant density during the whole growth period showed different effects. An increase in plant density showed a reduction in most parameters under assessment except for yield and biomass. Number of branches, number of pods per plant and number of seeds per plant were reduced with increase in plant density. Varieties with greater potential to perform in elevated plant densities were identified as Kaleya, Pan 1867 and Dina and were seen to be elastic while Magoye and SC Safari were inelastic. A correlation analysis indicated a strong relationship between yield and plant height, biomass yield, number of pods per plant and number of seeds per plant. A stepwise multiple regression indicated that plant height, biomass yield, number of pods per plant, number of seeds per plant and hundred seed weight contributed significantly to the total variation in grain yield. Kaleya, Pan 1867 and Dina can be recommended for production under increased plant population. It is, however, with caution that this recommendation is advanced because these results are coming from a single study conducted in one location and for one season. Validation of the findings through multilocation and seasons trials is recommended.

\section{ACKNOWLEDGEMENTS}

We are grateful to the Zambia Agriculture Research Institute (ZARI) for sponsorship of this research through the Agricultural Productivity Programme for Southern Africa (APPSA) project. Thanks also go to Seed Control and Certification Institute for support and allowing use of their field station as well as laboratory facilities. Finally, we acknowledge reviewers of the manuscript and statistical analysis.

\section{REFERENCES}

[1] Amissah-Arthur, A.A., S.S. Jagtap and E.E. Dashiell, 1999. "Plant density effects on growth and yield of tropical Soybean.” Tropical Science Journal, 39: 162-167.

[2] Ayub, M., M. Khalid, M. Tariq, M.A. Na Deem and M. Naeem, 2011. "Effect of different seeding densities and nitrogen levels on growth, forage yield and quality attributes of cluster bean (Cyamopsis tetraganoloba Tuab.)" Journal of Agricultural Technology, Vol. 7(5): 1409-1416.

[3] Ball, R.A., L.C. Purcell, E.D. Vories, 2000. "Shortseason soybean yield compensation in response to population and water regime." Crop Science Journal, 40: 1070-1078.

[4] Bing, L., X. Liu, C.Wang, J.Jin, S.J. Herbert, M .Hashemi, 2010. International Journal of Plant Production, 4(1), 1- 10.

[5] Biswas, P.K., M. Akhteruzzaman, G.N.C. Sutradhar and K.K. Biswas, 1997. "Effect of seed rates on grain yield and yield attributes of cow pea." Bangladesh Journal of Science, India Research, 32: 333-335.

[6] Bray, R.H. and Kurtz, L.T. (1945) Determination of Total Organic and Available Forms of Phosphorus in Soils. Soil Science. Vol 59: 39-45

[7] Bullock, D., S. Khan, A. Rayburn, 1998. "Soybean yield response to narrow rows is largely due to enhanced early growth." Crop Science Journal, 38 (4): 1011-1016. 
[8] Çalifikan, S., A. Mehmet, Ü. Ilhan and E.Ç. Mehmet, 2007. "The Effects of Row Spacing on Yield and Yield Components of Full Season and Double-Cropped Soybean." Turkey Journal of Agriculture and Forestry, , 31, 147-154.

[9] Casteel, S., 2011. Soybean Physiology: How well do you know soybeans? Purdue University Extension.

[10] Castillo, A.G., 1992. A study of production factors affecting seed vigour in garden peas (Pisum sativum L.) and the relationships between vigour tests and seed lot field and storage performance. PhD Thesis, Massey University, Palmerstone North, New Zealand.

[11]Egli, D.B., 1998. Seed Biology and Yield of Grain Crops. C.A.B. International, U.K.

[12] GenStat, 2010. 12th Edition: GenStat Procedure Library Release PL 20.2. VNS International Ltd., UK.

[13] Godfray, H. C., J. R. Beddington, I. R. Cute, L. Haddad, D. Lawrence, J. F. Miur, J. Pretty, S.

[14] Gomez, K.A. and A.A. Gomez, 1984. Statistical Procedures for Practical Research. 2nd Edition: John Wiley \& Sons, Inc. New York.

[15] Harold, K.H. and L. Fudi, 1992. Potential for increasing biological nitrogen fixation in soyabean. Kluwer Academic Publishers, Netherlands.

[16] IISD, 2014. Soyabean market: http://www.iisd.org/pdf/2014/ssi-2014

[17] IITA, 2009. Soybean: International Institute of Tropical Agriculture, Ibadan, Nigeria

[18] Lubungu, M., W.J. Burke, W.J. Sitko, 2013. Analysis of Soyabean Value Chain in Zambia's Eastern Province: Working Paper No.74, Indaba Agricultural Policy Research Institute, IAPRI, Lusaka.

[19] Martin, W. F., 1998. Soyabean: ECHO Technical Note: ECHO, 17391 Durrance Rd., North Ft. Myers FL 33917, USA.

[20] Mc Williams, D.A., D.R. Berglund and G.J. Endres, 1999. Soybean; Growth and Management Quick Guide. North Dakota State University and Extension Service, Minnesota.

[21] Mehmet, O., 2008. "Nitrogen rate and plant population effects on yield and yield components in soyabean." African Journal of Biotechnology Vol. 7 (24), pp. 4464-4470, 17 December, 2008

[22] Miti, J.M., 1995. Soybean (Glycine max (L) Merr.), in: Zambia Seed Technology, S.W. Muliokela, Ed, 195-199. Lusaka: Ministry of Agriculture, Food and Fisheries.

[23] Moe, S., 2012. Relationships of Soybean (Glycine max L.) accessions based on Agro-Morphological,
Physiological Traits and DNA Polymorphisms. Msc. Thesis, Suranaree University of Technology.

[24] Peoples, M. B., A.W. Faizah, B. Rerkasem and D. F. Herrigde, 1989. Methods for Evaluating Nitrogen Fixation by Nodulated Legumes in the Field: Australian Centre for International Agricultural Research, Canberra.

[25] Robinson, S. M. Thomas and C. Toulmin, 2010. Food security: The challenge of feeding 9 billion people. Science 327: 812- 818 .

[26] SCCI, 2013. Variety Register: Seed Control and Certification Institute, Chilanga, Zambia.

[27] Sekimura, T., T. Roose, P.K. Maini, J. Suzuki, T. Hara, 2000. The Effect of Population Density on Shoot Morphology of Herbs in Relation to Light Captured by Leaves. Ecological modelling. Elsevier Science B.V.

[28] Shamsi, K. and S. Kobraee, 2011. "Soybean Agronomic responses to plant density." Scholars Research Library: Annals of Biological Research, 2011, 2(4): 168-173.

[29] Shena, Y., C. Zhao, W. Liua, 2011. Seed Vigour and Plant Competitiveness Resulting from seeds of Eupatorium adenophorum in a persistent Soil Seed Bank. Flora206-Elsevier, 2011, 935-942.

[30] Squire, G.R., 1990. The Physiology of Tropical Crop Production, C.A.B. International, British Library, Wallingford, United Kingdom.

[31]UNZA, 2014. Practical Manual in Plant Nutrition. School of Agricultural Sciences: The University of Zambia, Lusaka.

[32] UPOV, 1998. Guidelines for the Conduct of Tests for Distinctness, Uniformity and Stability: Soyabeans (Glycine max (L.) Merrill), Geneva, Switzerland.

[33] USDA, 1999. Soil Taxonomy, 2nd Edition. A Basic System of Soil Classification for Making and Interpreting Soil Surveys: USDA, USA

[34]Wallace, A. and G. A. Wallace, 1993.Limiting factors, high yields and law of maximum. Horticultural Reviews.15: 410- 448. 